\title{
Use of metal-containing polymers as potential anticancer
}

\author{
agents \\ Charles E Carraher Jr ${ }^{1 *}$ and Michael R Roner ${ }^{2}$ \\ ${ }^{1}$ Florida Atlantic University, Department of Chemistry and Biochemistry, USA \\ ${ }^{2}$ University of Texas Arlington, Department of Biology, USA
}

\begin{abstract}
Metal containing polymers have been synthesized from a variety of metals that exhibit good inhibition of a variety of human cancer cell lines including pancreatic and breast human cancer cell lines. The products are rapidly synthesized using commercially available reactants and a system that is employed industrially allowing for ready expansion of the amounts of products synthesized. Recently, water soluble polymers have been synthesized using poly(ethylene glycol).
\end{abstract}

\section{Introduction}

We have been involved with including metals into polymers for various reasons. Much of this has been reviewed in a ten volume series [1] and various reviews for platinum [2-5], organotin [5-9], Group 5 [10,11] Group 15 [12-14], uranium [15], ruthenium [16] and vanadocene-containing [17] polymers. This brief review concentrates on the synthesis and characterization of metal-containing polymers for cancer treatment though they also offer good antibacterial, antifungal, and antiviral activity.

\section{Why polymers}

Potential advantages of using polymers as drugs has been reviewed by many $[2,6,9,18-22]$. The following briefly describes several of these potential advantages. A. Polymers limit movement of drugs because of their size. They are not as apt to move through membranes in the body. This may discourage build-up of in the kidneys and other organs decreasing renal and other organ damage. B. They may enhance activity through an increased opportunity for multiple bonding interactions between the target and the polymer. C. They can bypass the cell's defense system, specifically by being different (large size) the cells do not recognize them and/or are not prepared to deal with them. D. Large molecular weight molecules accumulate in solid tumors more than in normal tissues because of the enhanced permeability and retention effect, resulting in high amounts of polymers in the interstitial space due to a leaky vasculature and limited lymphatic drainage typical of tumors. This effect is referred to as the enhanced permeability and retention effect, EPR effect.

\section{Metal-containing drugs in the treatment of cancer}

A number of metal-containing drugs are known to be inhibit cancer cell growth. Two metal-containing drugs have been clinically tested. The platinum-containing drugs form the basis for many of the current drug treatments including cisplatinum II diamine, also known as cisplatin. We have synthesized a variety of platinum-containing polymers based on cisplatin that exhibit good ability to inhibit cancer cell growth [25]. Our polymers have lowered toxicity compared to cisplatin itself. As researchers know, while the cisplatin-drug types exhibit a broad range of anticancer activity, they also offer high toxicities.
The first non-platinum metal to undergo clinical trial was titanocene dichloride [23]. While the activity of cisplatin involves interaction with DNA, the activity for titanocene dichloride is related to its ability to react with transferrin [23-25]. Titanocene dichloride underwent Phase I clinical trials. The trials indicated a dose-limiting side effect associated with nephrotoxicity and a number of unwanted physical side effects including nausea, reversible metallic taste, pain during infusion, hypoglycemia, with these features undesirable. Counter, the absence of an effect on proliferative activity of the bone marrow, generally a dose-limiting side effect, was positive. Some phase II clinical trials were undertaken with patients with breast metastatic carcinoma and advanced renal cell carcinoma [23]. Unfortunately low activity discouraged further clinical study.

\section{Metal-containing polymers as anticancer agents}

Here we focus on the use of organotin, metallocene (mainly Group 4), and Group 15 metal-containing polymers as anticancer agents.

The overall reaction to form these polymers is based on the simple Lewis acid-base concept, illustrated in figure 1 for the reaction of camphoric acid, the Lewis base, and dimethyltin dichloride, the Lewis acid. Some of the philosophy in selecting the reactants is the focus on Lewis acids and bases that both exhibit some biological activity themselves with the hope that a synergetic effect occurs enhancing the ability to curtail cancer cell growth. In almost all cases the polymer exhibits a better ability to inhibit cancer cell growth than either of the reactants. We also find that the active agent is the polymer and not the degradation products [26]. This is consistent with studies that show that the polymers are stable in DMSO with half-chain lives, the time for the chain length to halve, generally in excess of 30 weeks [6-9]. In

Correspondence to: Charles E. Carraher Jr, Florida Atlantic University, Department of Chemistry and Biochemistry, Boca Raton, FL 33431, USA, E-mail: carraher@fau.edu key words: water soluble polymers, cancer, breast cancer, pancreatic cancer, organotin polymers, metallocene polymers

Received: October 04, 2017; Accepted: October 22, 2017; Published: October 25, 2017 

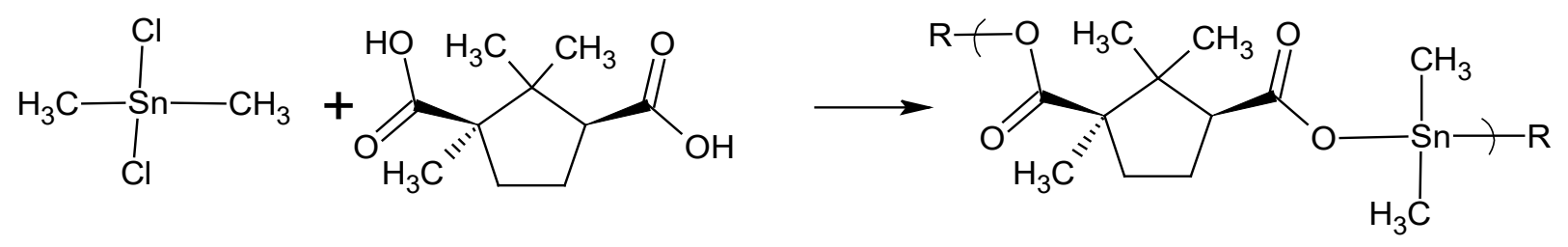

Figure 1. Repeat unit for the product of camphoric acid and dimethyltin dichloride where R represents simple chain extension.

other studies the polymers are found to be cytotoxic and cell death is by necrosis [6-8]. Most organometallic compounds associate with polar solvents such as DMSO and the biological results may be influenced by the presence of the DMSO [27-29]. For organometallic polymers covered here, the influence of DMSO on the tumor results is found to be minimal [30-32].

We employ the interfacial reaction system dissolving the Lewis base in water and the organotin, or other metal-containing reactant, in a suitable organic liquid such as heptane. The two reactants are mixed in a Waring blender and product is formed generally within 15 seconds. The product is polymeric with repeat units varying from 20 to 2,000 depending on the particular reaction conditions and reactants. Typically commercially available reactants are employed and the interfacial reaction system is used industrially to produce aromatic polyamides, aramids, and polycarbonates [33-35]. Thus, a straightforward path exists to form gram to ton quantities of the products.

The ability to inhibit cancer cell growth is determined employing the two most widely used measures. The initial measure describes the concentration of the drug that inhibits $50 \%$ cell inhibition after a specified exposure time. This term will be described as the effective concentration $\mathrm{EC}_{50}$. The $\mathrm{EC}_{50}$ values for our polymers range from milligrams $/ \mathrm{mL}$ to nanograms $/ \mathrm{mL}$ for $\mathrm{EC}_{50}$ values. The second measure of the potential effectiveness is the concentration of compound necessary to inhibit the standard cells compared to the concentration of drug necessary to inhibit the growth of the test cell line. A variety of symbols are employed to describe similar calculations. The term chemotherapeutic index, $\mathrm{CI}_{50}$, is employed by us. Thus, the $\mathrm{CI}_{50}$ is the ratio of the $\mathrm{EC}_{50}$ for the standard cell line divided by the $\mathrm{EC}_{50}$ for the particular test cell. Values greater than two are considered significant with some of our polymers having values greater than one thousand. Values for cisplatin are included for comparison.

In general, the nature of the metal has a marked effect on the overall ability to inhibit cancer cell growth. Thus, the most active based on the two biological markers, $\mathrm{CI}_{50}$ and $\mathrm{EC}_{50}$, are the metallocene polymers, followed by the organotin, and lastly those derived from the Group 15 metals (arsenic, antimony, and bismuth). Within the metallocenes, the hafnocene and zirconocene are the most active, highest $\mathrm{CI}_{50}$ and lowest $\mathrm{EC}_{50}$ values. Thus, had the researchers chosen these products to test rather than the titanocene product, we might have a new anticancer family of drugs in the market. For clarity, the inhibition curve is sigmoid and the $\mathrm{EC}_{50}$ determined at the midpoint of the curve. Once inhibition begins the concentration difference between the initial inhibition and final total inhibition is small with the region between initial inhibitions to final total inhibition essentially linear.

These metal-containing polymers show good inhibition of a variety of human cancer cell lines [9,10,36-42]. One focus is on pancreatic cancer since there is no good treatment once it has spread. Two pancreatic cancer cell lines are employed in the typical studies. These are the AsPC-1 cell line which is an adenocarcinoma pancreatic cell line and the PANC-1 cell line which is an epithelioid carcinoma pancreatic cell line. The two tested pancreatic cancer cells are human cell lines widely employed in testing for inhibition of pancreatic cancer. The AsPC- 1 cell line represents about $80 \%$ of the human cancers found. The PANC-1 represents about $10 \%$ of the human cancers detected. We also employ a pair of breast cancer cell lines. They represent a matched pair of cell lines. The MDA-MB-231 (strain number 7233) cells are estrogenindependent, estrogen receptor negative while the MCF-7 (strain line 7259) cells are estrogen receptor (ER) positive. Also typically included are the following: PC-3 (strain 3465) prostrate cell line, HT-29 (1507) human recto-sigmoid colon; and for control cells a WI-38 (ATCC CL75) normal embryonic cell line and NIH/3T3 mouse line cell line. And less usual we study resistant cell lines and other specialty cell lines.

\section{Water soluble polymers}

Polymer solutions employed in most industrial testing involve initially dissolving the test compound in dimethyl sulfoxide, DMSO, followed by addition of water. This is precisely the procedure employed by us. The greatest amount of water in our solutions is generally less than $0.1 \%$. Even so, the effect of the presence of water can have an effect on the biological activity. As noted before, this effect is not large for our polymers [29-31].

Water soluble drugs offer greater ease of treatment and delivery and they avoid possible side-effects due to the presence of DMSO. Poly(ethylene glycol), PEG, was employed to achieve this. PEG is known to assist biologically important molecules to become water soluble. PEG is relatively inexpensive and considered nontoxic. Further, there are a number of PEG chains available with differing end-groups and chain lengths so that tailoring the PEG is possible. In the future we plan to employ this variability to design systems that allow a focus on Lewis bases that offer good ability to inhibit unwanted pathogens and infectious agents but where the polymer is not water soluble. We are at the initial juncture of this study [43].

The synthesis of water soluble polymer organotin-containing polymers was initially achieved employing organotin polyethers as described in Figure 2 [44-46].

More recently we described the synthesis of analogous metallocenecontaining polyethers [47-49].

Lack of solubility is a major problem limiting efforts to employ Group 5 metallocenes as anticancer agents [50-56]. The present effort involving PEG offers an avenue allowing metallocene-containing small and large molecules to be soluble.

\section{Water-soluble polymers future}

A number of polymers that exhibit good ability to inhibit a range of cancer cell lines, viruses and bacterial agents have been synthesized. For instance, polymers from organotin (Figure 1) and metallocene (Figure 3,4) exhibit good ability to inhibit cancer cell lines. In fact, the hafnocene and zirconocene products show $\mathrm{EC}_{50}$ values in the 

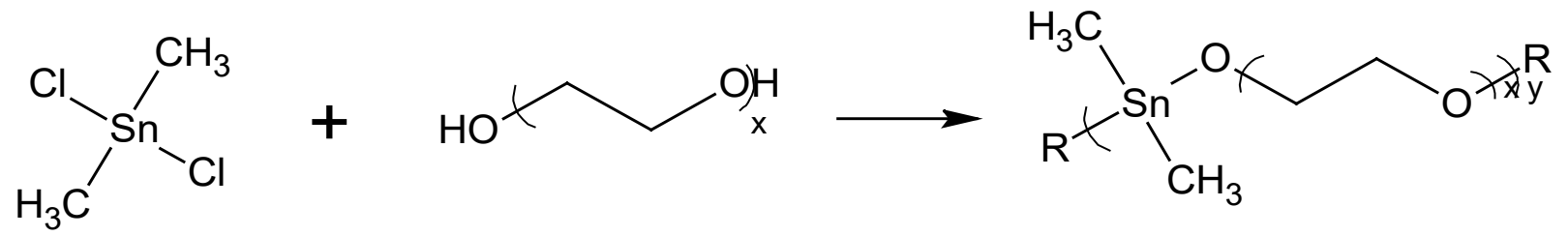

Figure 2. Synthesis of organotin polyethers from reaction of dimethyltin dichloride with PEG where $\mathrm{x}$ is the chain length for the PEG and $\mathrm{y}$ is the chain length for the polymer; $\mathrm{R}$ is simple chain extension.
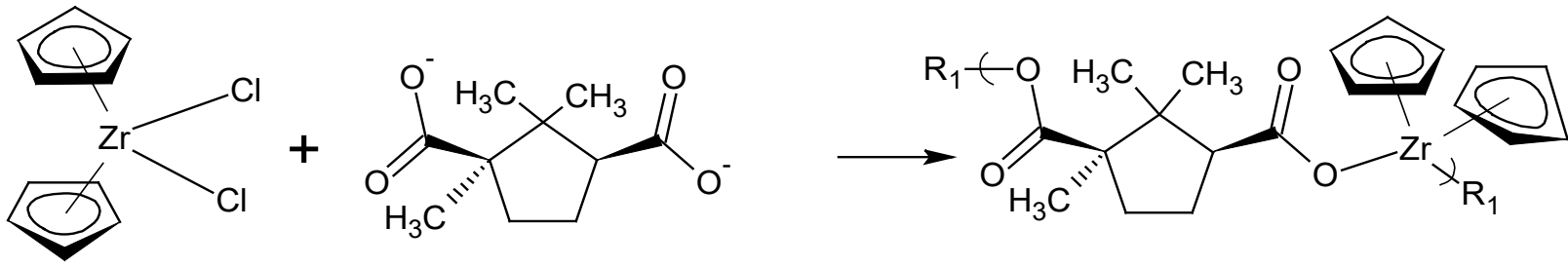

Figure 3. Reaction scheme for the reaction between D-camphoric acid and zirconocene dichloride where $\mathrm{R}_{1}$ represents simple chain extension.

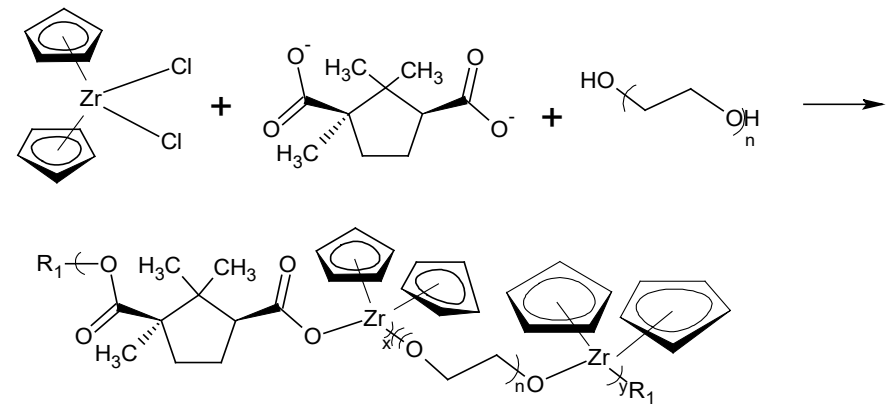

Figure 4. Reaction scheme for inclusion of $\mathrm{PEG}$ into the $\mathrm{Cp}_{2} \mathrm{Zr} /$ camphoric acid product.

nanogram $/ \mathrm{mL}$ range and $\mathrm{CI}_{50}$ values in the thousands but they are not water soluble. We are currently working at creating water soluble derivatives through formation of co-polymers from reaction of the metallocene dihalides in the presence of camphoric acid and PEG.

The synthesis and study of water-soluble metal-containing polymers has begun. The results are promising allowing the synthesis of water-soluble products that exhibit good inhibition of a host of cancer cell lines. This is the beginning of a long journey.

\section{References}

1. Abd-El-Aziz A, Carraher C, Pittman C, Sheats J, Zeldin M (2003) Macromolecules Containing Metal-and Metal-Like Elements, Vol. 1, A Half Century of Metal-and Metalloid-Containing Polymers, John Wiley \& Sons, Hoboken, NJ.

2. Siegmann-Louda D, Carraher C (2004) Polymeric platinum-containing drugs in the treatment of cancer; Biomedical Applications, John Wiley \& Sons, Hobokin, NJ.

3. Roner MR, Carraher C (2008) Cisplatinum derivatives as antivirial agents, Inorganic and Organometallic Macromolecules, Springer, New York, NY.

4. Carraher C, Francis A (2011) Water-Soluble Cisplatin-Like Chelation Drugs from Chitosan. J Polym Mater 28:189-203.

5. Roner MR, Carraher CE Jr, Shahi K, Barot G (2011) Antiviral Activity of MetalContaining Polymers-Organotin and Cisplatin-Like Polymers. Materials (Basel) 4: 991-1012. [Crossref]

6. Carraher C, Siegman-Louda D (2004) Organotin macromolecules as anticancer drugs; In Macromolecules Containing Metal and Metal-like Elements. Vol. 3. Biomedical Applications. John Wiley \& Sons, Hobokin, NJ.

7. Carraher, C (2004) Organotin polymers in Macromolecules Containing Metal and Metal-like Elements. Vol. 3. Biomedical Applications. John Wiley \& Sons, Hobokin, NJ.

8. Carraher CE, Roner MR (2009) Organotin Polyethers as Biomaterials. Materials (Basel) 2: 1558-1598. [Crossref]
9. Carraher CE, Roner MR (2014) Organotin polymers as anticancer and antiviral agents. J Organomet Chem 751: 67-82.

10. Carraher C (2006) Zirconocene and hafnocene-containing macromolecules. In Macromolecules Containing Metal and Metal-like Elements. Vol. 6. Transition MetalContaining Polymers. John Wiley \& Sons, Hobokin, NJ.

11. Carraher C (2005) Condensation metallocene polymers. J Inorg Organometal Polyms 15: $121-145$

12. Carraher C (2008) Organoantimony-containing polymers. J Polym Mater 25: 35-50.

13. Carraher C (2008) Antimony-containing polymers. Inorganic and Organometallic Macromolecules, Springer, New York, NY.

14. Carraher C, Roner MR, Thibodeau R, Moric-Johnson A (2014) Synthesis, structural characterization, and preliminary cancer cell study results for poly(amine esters) derived from triphenyl-group VA organometallics and norfloxacin. Inorganica Chem Acta 423: 123-131.

15. Carraher C (2005) Uranium-containing polymers. In Macromolecules Containing Metal and Metal-like Elements, Vol. 5. Metal-Coordination Polymers. John Wiley \& Sons, Hobokin, NJ.

16. Carraher C, Murphy AT (2005) Ruthenium-containing polymers for solar energy conversion. In Macromolecules Containing Metal and Metal-like Elements. Vol. 5. Metal-Coordination Polymer. John Wiley \& Sons, Hobokin, NJ.

17. Sabir T, Carraher C (2008) Vanadocene-containing polymers. Inorganic and Organometallic Macromolecules. Springer, New York, NY.

18. Neto W, Pena L, Ferreira G, Souza Junior F, Machado F (2017) Target delivery from modified polymers to cancer treatment. Current Org Chem 21: 4-20.

19. Conner E, Lees I, MacLean D (2017) Polymers as drugs-advances in therapeutic applications of polymer binding. J Polym Sci A Polym Chem 55: 3146-3157.

20. Vogis D, Krishnan V, Mitragotri S (2017) A review on engineering drug conjugates to improve combination chemotherapy. Colloid Interface Sci 31:75-85.

21. Oh JK (2017) Polymers in Drug Delivery: Chemistry and Applications. Mol Pharm 14 2459. [Crossref]

22. Connor E, Lees I, Maclean D (2017) Polymer drugs-advances in therapeutic application of polymer binding agents. J Polym Sci A Polym Chem 55: 3146-3157.

23. Lümmen G, Sperling H, Luboldt H, Otto T, Rübben H (1998) Phase II trial of titanocene dichloride in advanced renal-cell carcinoma. Cancer Chemother Pharmacol 42: 415417. [Crossref]

24. Roat-Malone RM (2007) Bioinorganic Chemistry. ( $2^{\text {nd }}$ edn), John Wiley \& Sons, New York, NY.

25. Waern JB, Harris HH, Lai B, Cai Z, Harding MM, et al. (2005) Intracellular mapping of the distribution of metals derived from the antitumor metallocenes. $J$ Biol Inorg Chem 10: 443-452. [Crossref]

26. Carraher C, Barot G, Vetter SW, Nayak G, Roner MR (2013) Degradation of the organotin polyether derived from dibutyltin dichloride and hydroxyl-capped poly(ethylene glycol) in trypsin and evaluation of trypsin activity employing light scattering photometry and gel electrophoresis. J Chin Adv Mater Soc 1: 1-6. 
27. Abdelkarim, A, Al-Shomrani, M, Rayan, A, El-Sherif, A (2015) Mixed ligand complex formation of cetirizine drug with bivalent transition ions in the presence of 2-aminomethyhlbenzimidazol: synthesis, structural, biologic metric and thermodynamic tudies. $J$ Soln Chem 44: 1673-1704.

28. Gjevig Jenson K, Onfelt A, Wallin M, Lidumas V, Andersen O (1991) Effects of organotin compounds on mitosis, spindel structure, toxicity, and in vitro microtubule assemble. Mutagenessis 6: 409-4-16. [Crossref]

29. Peres, G, Leite, D, Pesce de Sileira, N, (2016) Study of complexes formation between transition metal ions and amylopectin DMSO/H2O solution. Starch/Staerke 68: 1129-1138.

30. Carraher C, Barot G, Shahi K, Roner MR (2007) Synthesis, structural characterization, and ability to inhibit cancer cell growth of a series of organotin poly(ethylene glycols). J Inorg Organometal Polym 17: 595-603.

31. Carraher C, Roner MR, Barot G, Shahi K (2014) Comparative anticancer activity of water-soluble organotin poly(ethylene glycol) polyethers. J Polym Mater 31: 123-133.

32. Carraher C, Barot G, Shahi K, Roner MR (2013) Influence of DMSO on the inhibition of various cancer cells by water soluble organotin polyethers. J Chin Adv Mater Soc 1: 294-304.

33. Carraher C (2003) Giant Molecules. (2 ${ }^{\text {nd }}$ Edn). Wiley-Interscience, New York, NY.

34. Carraher C (2017) Introduction to Polymer Chemistry. (4 $4^{\text {th }}$ Edn). Taylor and Francis, New York, NY.

35. Carraher C (2018) Polymer Chemistry. (10 th Edn). Taylor and Francis, New York, NY.

36. Carraher C, Roner MR, Crichton R, Moric-Johnson A, Miller L, et al. (2016) Synthesis and preliminary cancer cell line results for the product of organotin dihalides and alphacyano-4-hydroxycinnamic acid. J Inorg Organometal Polym Chem 26: 1351-1361. [Crossref]

37. Carraher C, Slawek C, Roner MR, Moric-Johnson A, Miller L, et al. (2016) Synthesis and structural and initial cancer cell line characterization of organotin polyesters from dipicolinic acid. J Inorg Organometal Polym Chem 26: 1338-1350.

38. Carraher C, Truong NTC, Roner MR (2017) Synthesis of metallocene poly(ether esters) from reaction with glycyrrhetinic acid. J Polym Mater 34: 435-454.

39. Carraher C, Roner MR, Sooledo N, Moric-Johnson A, Miller L, et al. (2017) Synthesis and initial cancer cell results of organotin polyethers derived from the anticoagulant dicumarol. Int J Applied Pharm Biological Res 2: 1-17.

40. Carraher C, Roner MR, Black K, Frank J, Moric-Johnson A, et al. (2017) Polyesters from reaction of 3,5-pyridinedicarboxylic acid and group V-containing dihalides and their preliminary and comparative abiliy to inhibit cancer cell growth. Int J Appl Pharm Biol Res 2: 1-17.

41. Carraher C, Roner MR, Campbell A, Moric-Johnson A, Miller L, et al. (2017) Group IVB metallocene polyesters containing camphoric acid and preliminary cancer cel data. International Journal of Polymeric Materials and Polymeric Biomaterials.
42. Carraher C, Roner MR, Mosca F, Moric-Johnson A, Miller L, et al. (2017) Synthesis and characterization, including cancer cell line inhibition, of group VA (group 15)-containing polyesters from reaction with camphoric acid. $J$ Inorg Organomet Polym Mat 27: 1627-1639.

43. Carraher C, Roner MR, Black K, Frank J, Moric-Johnson A, et al. (2017) Polyesters from reaction of 3,5-pyridinecarboxylic acid and group $\mathrm{V}$-containing dihalides and their preliminary and comparative ability to inhibit cancer cell growth. Int $J$ Applied Pharm Biol Res 2: 1-17.

44. Carraher C, Barot G, Shahi K, Roner MR (2007) Synthesis, structural characterization, and ability to inhibit cancer cell growth of a series of organotin poly(ethylene glycols) J Inorg Organometal Polyms 17: 595-603. [Crossref]

45. Carraher C, Roner MR, Barot G, Shahi K (2014) Comparative anticancer activity of water-soluble organotin poly(ethylene glycol) polyethers. J Polym Mater 31: 123-133.

46. Carraher C, Barot G, Shahi K, Roner MR (2013) Influence of DMSO on the inhibition of various cancer cells by water soluble organotin polyethers. J Chin Adv Mater Soc 1: $294-304$

47. Carraher C, Roner MR, Frank J, Moric-Johnson A, Miller L, et al. (2017) Synthesis of water soluble group 4 metallocene and organotin polyethers and their ability to inhibit cancer. Processes 5: 1-13.

48. Carraher C, Roner MR, Black K, Frank J, Moric-Johnson A, et al. (2017) Synthesis, structural characterization and initial anticancer activity of water soluble polyethers from hafnocene dichloride and poly(ethylene glycols). J Chim Adv Mater Soc 5: 254268. [Crossref]

49. Carraher C, Roner MR, Reckleben L, Black K, Frank J, et al. (2016) Synthesis, structural characterization and preliminary cancer cell line results for polymers derived from reaction of titanocene dichloride and various poly(ethylene glycols). $J$ Macromol Sci A 53: 394-402. [Crossref]

50. Benítez J, Guggeri L, Tomaz I, Pessoa JC, Moreno V, et al. (2009) A novel vanadyl complex with a polypyridyl DNA intercalator as ligand: a potential anti-protozoa and anti-tumor agent. J Inorg Biochem 103: 1386-1394. [Crossref]

51. Strohfeldt K, Tacke M (2008) Bioorganometallic fulvene-derived titanocene anticancer drugs. Chem Soc Rev 37: 1174-1187. [Crossref]

52. Beckhove P, Oberschmidt O, Hanauske A, Pampillon C, Schirrmacher V, et al. (2007) Antitumor activity of titanocene $\mathrm{Y}$ against freshly explanted human breast tumor cells and in xenografted MCF-7 tumors in mice. Anticancer Drugs 18: 311-315. [Crossref]

53. Harding MM, Mokdsi G (2000) Antitumour metallocenes: structure-activity studies and interactions with biomolecules. Curr Med Chem 7: 1289-1303. [Crossref]

54. Olszewski U, Claffey J, Hogan M, Tacke M, Zeillinger R, et al. (2011) Anticancer activity and mode of action of titanocene C. Invest New Drugs 29: 607-614. [Crossref]

55. Olszewski U, Hamilton G (2010) Mechanisms of cytotoxicity of anticancer titanocenes. Anticancer Agents Med Chem 10: 302-311. [Crossref]

56. Roat-Malone RM (2007) Bioinorganic Chemistry. ( $2^{\text {nd }}$ edn), Wiley, New York, NY.

Copyright: ( 2017 Carraher CE. This is an open-access article distributed under the terms of the Creative Commons Attribution License, which permits unrestricted use, distribution, and reproduction in any medium, provided the original author and source are credited. 